\title{
Land Rights as an Imperative for Sustainable Land and Natural Resources Management in Kenya
}

\author{
Leonard Omullo Orondo \\ National Land Commission, Nairobi, Kenya
}

\begin{abstract}
During the colonial administration in Kenya, land was managed using complex administrative structures, which were generally inefficient and unproductive. Key land reforms were postulated in the Land Policy developed in 2009, and subsequently in the Kenya Constitution 2010. However, failure to fully implement the intentions of the policy and the Constitution has put the goals of sustainable land and land resources management in jeopardy. A major contributor of this phenomenon has been the political economy in the country. Vested political and economic interests have ensured that radical reforms in the land sector do not see the light of the day. This situation may be addressed by improved governance structures and more public participation in decision-making up to the grassroots level. The paper notes that the process of recognizing and accurately recording and managing records on land rights is a key ingredient in the protection of land rights. It further argues that the private land tenure system is an impediment to the realization of land rights of the weaker sections of society and points out that the three tier land tenure system in Kenya (public, private and Community), does not adequately address the bundles of rights in Land and land based natural resources.
\end{abstract}

Keywords: indigenous people, land rights, land tenure, land reforms, public participation, political economy

\section{Introduction and Background}

During the colonial administration in Kenya, land was managed using complex administrative structures, which were generally inefficient and unproductive. There were a plethora of legal and policy instruments, which were never in harmony, and that made the process of land administration complex and inefficient. Lack of a land policy in Kenya, further complicated the situation, leading to unsustainable land use.

Following independence, the new leaders entrenched their own interests at the expense of the majority poor Kenyans, by perpetuating the colonial economy, and partially co-opting the leaders of the independent movements. As a result the majority poor remained sidelined, not only within the economy, but also with respect to their land rights. Landlessness then became a thorny issue for the new rulers, prompting them to appease the vocal activists still clamoring for land taken from them by the colonialists.

This created the process of agitation for more democratization of the administrative and governance systems within these Governments. This took the form of agitation for more involvement in decision-making, more pluralistic systems of governance, ushering in multiparty politics. There was less focus on the need for reforms in the governance and management of land and land based resources. The emerging elites controlled land through legislations and retention of colonial administrative structures. 
This control caused disparities in access to land and land use between the dominant elites and the general peasantry, with the latter taking very subsidiary user rights. The elite also controlled most of the economic means of production, and land acquisition was just an additional asset for the same. This represents the initiation of disparities in land rights which impacted negatively on access and use of land and land resources for the less privileged.

In Kenya, land was managed for a very long time after independence without any policy. There existed several statutes, which at times conflicted and rendered general land administration and management inefficient and unproductive (Sessional Paper No. 3, 2009). This system of administration gave rise to poor recording and insecurity of land rights, land conflicts, environmental degradation, land fragmentation, among other indicators of unsustainable land management (Sessional Paper No. 3, 2009). The land rights of the minorities, vulnerable, and other specialized groups were trampled upon. Public land was vested in the executive, who allotted this with abandon, not sparing even areas such as forests and protected areas (personal observation).

Key land reforms, accompanied with policy, legal and institutional reforms, were postulated in the Land Policy of 2009; and subsequently in the Kenya Constitution 2010. The Constitution of Kenya (COK), Chapter Four on the Bill of Rights provides for the rights of all Kenyans, and allows an individual to petition a court of law for violations meted on third parties. For instance, Article 40 protects the freedom to own property, including land, in any part of Kenya. Article 42 protects the rights to access a clean and healthy environment. Article 43 protects the rights to housing and food security. Article 56 protects the rights of the minorities and marginalized groups. These are just some of the Constitutional provisions on fundamental human rights in Kenya. The Constitutional reforms included a full chapter on land and environment (Chapter Five) and provided for the National Land Commission, as an independent institution, far removed from the executive, to carry out a host of land reforms identified in the policy.

A National Land Policy, developed as Sessional Paper No. 3 of 2009, promised to bring radical reforms in the land sector. The policy had the stated goal of achieving an efficient, productive and sustainable management of land in Kenya. It had streamlined the legal and institutional frameworks, fundamentally by merging the plethora of legislations into just three major land laws: the Land Act, 2012, the Land Registration Act, 2012, and the National Land Commission Act, 2012. The latter also provided for the creation of the National Land Commission as an independent institution to manage land and implement the much needed reforms, critical for sustainable management of land.

However, the National Land Commission(NLC), has to date failed to live up to the high expectations of Kenyans, to spur radical reforms in the land sector, that would have enhanced tenure security, centralized land information, improved land administration, and a general improvement and governance of land for sustainable development. This failure to fully implement the intentions of the policy and the Constitution has put the goals of sustainable land and land resources management in jeopardy. A major contributor to this unfortunate situation, has been the political economy in the country: Vested political and economic interests, plus lack of adequate public awareness, have ensured that radical reforms in the land sector do not see the light of the day. In fact, there has been a number of recent amendments by parliament, to the land Acts, all aimed at repositioning the executive, to its former authority in land administration and management, notwithstanding the poor record on the same, for decades.

This situation may be addressed by improved governance structures and more public participation in decision-making in the sector. Even though the Constitution of Kenya 2010, a radical reform itself, provides for 
public participation, there are no universally acceptable norms and guidelines on how this ought to be carried out, and what therefore forms the threshold for adequate public participation. This is an imperative if land rights of all Kenyans are to be achieved, especially the land rights of the weaker, vulnerable, minority and marginalized communities, and segments of society. The locals need to know through simple methods, such as maps, photos, etc.; where their lands are, who owns what, and what's happening to the land, real-time. This role would better be accomplished through the establishment of a local land information system (LIS).

The process of recognizing and accurately recording and keeping records on land rights is a key ingredient in the protection of land rights. There is need to develop local records on land, which is repeated at the National level, for local level decision support. A key reform proposed in this area was the creation of a National Land Information Management System (NLIMS), with retrievability and public interface to be managed by the National Land Commission. This was aimed enhancing and improving the processes of land administration and management; adjudication and survey towards efficiency, and transparency. Not only has NLIMS been returned to the Ministry of Lands, an executive arm, but the role of the commission has only been restricted to public land management, in a suit of land amendments carried out in 2016. In order to record and protect land rights, the processes of land administration, adjudication, and survey will need to be improved. Besides, there is a critical need to integrate adequate public participation, inclusive of local leadership in the process for validation and monitoring purposes.

The Current Land Control Boards (LCBs) in the counties should be abolished and replaced by the former County Land Management Boards (CLMBs) led by a secretary appointed by the National Land Commission. This is because the Land Control boards are not transparent, and fully appointed by the executive. Further there is need to devolve the land administration to the lower levels of a clan, under the leadership of a chief or clan elder/local administrator. The office of the chief should be regulated, complete with allowances for clan representatives and disciplinary measures for breaches of protocol. This will make that office accountable, while the allowances will provide the requisite incentives.

The National Land Commission should be revamped in line with desired reforms, and allowed to collect fees and levies for its administrative purposes.

\section{Land Rights, Land Use, and Sustainable Development}

Land is a finite resource held as a source of wealth, financial security, and livelihoods across generations (Ellis \& Galvin, 1994). In Kenya, land is a fundamental source of production, with the majority using it for agricultural productivity. Land tenure is the means by which people get access and user rights of land and natural resources. It logically follows that an inflexible non-transparent, non-efficient tenure regime will certainly compromise the realization of land rights security; access and use, and consequently socio-economic development. To date the country cannot boast of having come out of the woods on allocation and respect for tenure rights to all categories of people, as postulated in the Land Policy of 2009 and the Constitution 2010. Pastoral lands, community lands, and land belonging to the minorities and vulnerable groups are consistently grabbed, in cahoots' with local leaders; in violation of existing laws such as the Community Land Act, 2016. This is why public participation, particularly at the grassroots, becomes a critical ingredient in land administration and management.

Few studies have been carried out on land tenure and its effects on socioeconomic development in Kenya. Ntiati (2002) carried a study on the socioeconomic effects of group ranches sub-division in Kajiado and 
Lokitiktik Districts and found that sub division of land led to the marginalization of communities in political, social, and economic terms. Waiganjo and Ngugi (2001) investigated the effect of the existing land tenure system on land use in Kenya. They found that land tenure types and policies had a direct influence on land use practices. Johnson (1972) investigated whether different land tenure systems resulted in wealth maximization. He concluded that for a particular land tenure system to result into wealth maximization, there must be a definition and allocation of property rights, and a method of distributing the income earned from land so that this acts as an incentive for economic agents to use land for the most productive use, and minimal restrictions to the sale of land. These studies illustrate links between land tenure, land use, and productivity. Sectoral productivity of land is what will enhance socioeconomic development, among other factors. Therefore, no sustainable development will be achieved if there are intrinsic challenges with land tenure, land rights, and land use. Land tenure must comprehensively capture all identifiable land rights for it to promote sustainable use of land and land based natural resources.

The land based natural resources contribute directly to the socioeconomic well-being of the people, through the continuous provision of goods and services.

\section{Land and Land Resource Legislations}

The Kenya Constitution 2010 and the Land Policy of 2009 have provided a synergistic basis on which to attain sustainable land and natural resources management.

However, the non-development of relevant legislations to operationalize critical aspects of land and resources management, are likely to deny concerned population their land rights. For instance, following the enactment of the Constitution, 2010 and the National Land Commission in 2012, land use laws were supposed to be harmonized to reflect these aspirations (COK, 2010, Article 68b). This has not been effected to date, with the consequence of compromising the oversight role of the National Land Commission to manage public land and other land based resources. This is because it is the implementation of Article 68b, which should have legally ingrained the Commission's role into sectoral land legislations. Consequently, the Commission has no direct entry point, in the management of sectoral land resources such as Water, minerals, forests, wildlife, and environment, as provided for in the Constitution. This leaves the respective lead agencies for these resources, unsupervised, and inadequately accountable to the people of Kenya.

Where there has been progress to revise these legislations, a common bias to revert to the centralized Government control has been observed. The roles of the County Governments in devolved functions in the sector have equally been dimmed.

The revision of the Land Laws of 2012 in the format of the "Omnibus Land Laws", returned critical powers to the executive, which has quite a poor profile in respecting the rights of land users and overall management of land. The amendments to the Community Land Act, 2016, also eroded the centrality of communities in community land and land resources management plus benefit sharing. All these strategic amendments have stifled the pace of the anticipated reforms in the land sector, with consequences on land access, decision-making, and respect for land rights.

Land and land resources in Africa, including Kenya, are increasingly governed by modern systems and less by customary systems. Unfortunately, changing land use and land ownership patterns has not been accompanied by policies, legal and institutional reforms. There has been widespread wave of land reforms associated with political and social reforms in Africa following more democratization. There is need to ensure that appropriate 
land rights, complete with reformed legal and institutional frameworks, accompany these processes.

Improved legislation and policies alone may not achieve this, as has been demonstrated by the sidelining, at times sabotage of the Land Policy of 2009 and the Kenya Constitution, 2010, by various interest groups. There is more need for public participation frameworks through various modes of participatory management to fix this malaise. Worse, at times, even passages of relevant legislations are ignored or slowed by parliament, notwithstanding specific directions in the Constitution that they be passed. For instance, the Kenyan parliament has harmonized the land laws, but failed to do the same for land use laws (Article, 68b), which pertains to natural resources. This has thwarted controls and regulations on natural resources management and exploitation. Without significant controls in resource management, well connected private individuals will continue to exploit natural resources to their own benefits, notwithstanding a clear recognition in the Constitution that resources belong to all the peoples of Kenya. Clearly the land rights of a wide section of populations will be sidelined, with the minority, vulnerable communities, being most affected.

Poor tenure regimes will enhance unsustainable land use practices and poverty thereby compromising sustainable land and natural resources management, including the Sustainable Development Goals (SDGs). There is therefore, need to protect the weaker sections through effective community land regulations and integration of indigenous knowledge in the management of community lands. The Kenya Constitution provides the protection of special categories land rights, such as indigenous and pastoral communities.

But unless these rights find location in revised policies, legislations, and land regulations, followed by participation strategies, implementation will remain distant; notwithstanding the recognition in several international statues, such as the UN charter, ILO laws, etc..

\section{Land Tenure, Land Rights, and Land Use}

Land is a finite resource held as a source of wealth, financial security, and livelihoods across generations (Ellis \& Galvin, 1994). There is an intrinsic linkage between land tenure, land rights, and land use. Land tenure is the means by which people get access and user rights of land and natural resources. In Kenya, land is a fundamental source of production, with the majority using it for agricultural productivity. It logically follows that an inflexible non-transparent, non-efficient tenure regime will certainly compromise the realization of land rights security; access and use, for socio-economic development. This will also promote unsustainable land use practices.

Currently, Kenya has three types of land tenure regimes: public, private, and community land tenure regimes. These tenure regimes, as the only administrative structures for ensuring land tenure rights within Kenya, are clearly inadequate to provide for that. Improved legislation and policies alone may not adequately secure the spectrum of land rights that may be in attendance. The private land ownership model is specifically put to question in the Kenyan context, as it actually dislocates the realization of land rights to the economically weaker segments of society. It commoditizes land in contradiction to the aspirations of its own land policy direction. Nonetheless, the Constitution protects private ownership of land. The same constitution protects the interests of the minorities and vulnerable groups. Thus the stated tenure regimes do not capture the full intentions of the land policy and legal documents. However, mixes of tenure regimes or customized tenure may be more appropriate to cover for various land and resources rights, e.g., the carbon credit rights and other rights under the realm of "bundle of rights". Further, there is more need for new public participation frameworks through various modes of participatory management to fix this malaise. 


\section{Land Rights of Indigenous Communities}

The land rights of the indigenous communities, such as the Ogieks in Kenya need to find location in revised sectoral policies, legislations, and land regulations. Despite the recognition of these rights in several local and international statues, such as the UN charter, ILO laws, they remain unrealized because of not being mainstreamed into the sectoral legislations in Kenya.

The idea that local people do have a right to use, own, and control developments on their land has created the issue that land rights are indeed human rights. Land rights do not just impact on individual property rights, but are central to social justice.

Indigenous people have argued that their culture will disappear without strong protection to their land rights. Indigenous communities argue that territories are not just their source of livelihoods, but also the source of their spiritual, cultural, and social identity. In Kenya, the push by the indigenous Ogieks to be allowed to continue staying within protected forests, such as Mau forest, Mt. Elgon forests, and Embobut forest has caused intense debate and even a successful litigation in the African Court of Justice for the recognition of their land rights. However, currently, implementations of such court rulings have ran into conflicts with the goals of current forest legislations (Forest Management and Conservation Act, 2016). The said forest act is in conflict with these rights because of the anti-conservation land use practices such as cultivation and charcoal burning by these communities. Besides, the populations of some of such indigenous communities have since increased, making their land use activities more negative in impacts.

Recent figures indicate that nearly half of global rural populations do not enjoy security of tenure in land, and that this is a major cause of poverty (United Nations Human Settlements Program, 2008). The idea that local people do have a right to use, own, and control developments on their land has created the issue that land rights are indeed human rights.

It is suggested in this paper that improved governance structures, promotion of local level land use planning; a restructuring of the political economy, public participation in decision-making, change/modifications of tenure regimes, issues of benefit sharing from resource exploitation as rights to land, control of land markets to prevent land speculation and hoarding, and formulation of innovative land taxation regimes/other incentives to regulate land use; are some of the ingredients necessary to safeguard the land rights of the different segments of the Kenyan society and ensure equity in ownership and access. The land policy of 2009, also recognized the need for improved access to land.

\section{Land as a Human Rights Issue}

Land rights are basically human rights issues. These rights broadly refer to rights to use, control, and transfer a parcel of land. They include rights to: occupy, enjoy, and use land and resources; restrict or exclude others from land; transfer, sell, purchase, grant or loan; inherit and bequeath; develop or improve; rent or sublet; and benefit from improved land values or rental income (FAO, 2002).

Internationally, no treaty or declaration specifically refers to a human right to land. In fact, strictly speaking there is no human right to land under international law. Strictly, land rights are human rights issues. Land rights constitute the basis for access to food, housing, and development, and without access to land many people find themselves in a situation of great economic insecurity. Therefore, control of rights to land has historically been an instrument of oppression and colonization. For instance, land right was used as a center piece of apartheid South Africa. 
In the worst situations, stratification in land access has been an ingredient in violent conflicts. The situation in the Occupied Palestinian Territories and Israel is a vivid illustration on the use of land rights as a means of oppression (Hussein \& Mckay, 2003).

Land rights play a catalytic role in economic growth, social development, and poverty alleviation (International Land Coalition, 2003). Recent figures indicate that nearly half of global rural populations do not enjoy security of tenure in land, and that this is a major cause of poverty (United Nations Human Settlements Program, 2008). Land reforms are usually necessary to deal with issues as poverty, equity, restitution for past expropriation, investment, and innovation in agriculture or sustainability.

Arable land is becoming increasingly valuable due to greater investor interests, population growth, migration, and climate change. These interests also include large scale land acquisition, which has been labeled "land grabbing". This has raised the issue of the rights of the local population to access land for food security. The recent focus on climate change-offsetting measures, which has generated the acquisition of large tracts of lands to plant palm oil or other sources of bio-fuels, is likewise creating a pattern of acquisition of land for economic gains to the detriment of the local populations, who are losing their lands to international investors. The idea that local people do have a right to use, own, and control developments on their land has created the issue that land rights are indeed human rights. Land rights do not just impact on individual property rights, but are central to social justice. Land rights have been recognized within the context of gender equality. Women land rights are often dependent on marital status, which automatically causes bias and discrimination.

The Constitution of Kenya has recognized the right of women to own parental land (The Constitution of Kenya, 2010). However, implementation is proving a challenge as married women also inherit the husband's land, and the proposal goes against the cultural grain in some communities in Kenya. Kenya has been able to develop and sell carbon credits from Kasigau Hills Forests in Taita Taveta County, while several international firms have been looking for large tracks of land for investment purposes. Without clear tenure security for the local populations, no equity is realized from such resource exploitations, focusing on land.

Where does this leave the integrity of private land tenure system, especially in Kenya where few individuals own large tracks of land? Land represents not only a very valuable economic asset but is also a source of identity and culture. It therefore demands that regulations and policies on tenure be carefully crafted so as not to jeopardize the land rights of certain segments of the community. Clearly private land tenure system compromises the land rights, access to land, and use by the economically and politically weaker sections of the community.

Indeed the Kenya land policy philosophy (Section 29) states that "land is not just a commodity to be traded in the market, but has multiple values which should be protected” for equitable use by generations. But this did not find any location in the Land Laws, 2012, nether have the markets been managed or regulated in any objective manner to realize equitable access and use. This represents another case of elite capture towards land reforms. This then becomes an impediment to the realization of equity in land rights. A national discourse is called for to debate these issues, and chart a way forward.

Currently, Kenya has three types of land tenure regimes: public, private, and community land regimes. These tenure regimes as the only administrative structures for ensuring land tenure rights within Kenya are clearly inadequate to cover the multiple rights highlighted above.

The right to food has been recognized by international human rights law. A human rights approach to land rights is critical to addressing pre-conflict, conflict, and post-conflicts situations. Whereas land has been 
exclusively commodified as a commercialized good, a human rights approach to land rights brings into sharp focus, the value of land as a social and cultural asset, by suggesting that it is a fundamental human right.

\section{Discussion and Conclusions}

Land rights affect access, use, and productivity of land by any particular community or category of persons. Political reforms, aimed at social-economic transformations, should also address the institutional, policy, and legal dimensions of land rights. Equally land rights, though not explicitly covered within the realms of international human rights law, have various dimensions of human rights and are indeed recognized as fundamental human rights. The violation and non-protection of these rights, leads to discrimination in access and use of land, and consequently negative impacts on sustainable development.

Even though Kenya has developed a progressive Land Policy (2009), legislations and Constitution (2010), there is very little to show for land reforms due to several factors such as lack of political will and elite capture. In order to promote sustainable development and efficient use of land, and land based resources, improved land governances accompanied by legal and institutional reforms are required. But these in themselves, will not suffice to achieve the desired guaranteed land rights for all, because these can always be sabotaged or ignored by vested interests. In order to address the negative factor of interest groups, participatory governance approaches involving local leaders and populations in land administration will be inevitable. This requires unanimity on agreed public participation thresholds and institutions required for land administration and management. The Current Land Control Boards (LCBs) in the counties should be abolished and replaced by the former County Land Management Boards (CLMBs) led by a secretary, appointed by the National Land Commission. This is because the Land Control Boards are not transparent, or always impartial, and fully appointed by the executive. Further, there is need to devolve the land administration to the lower levels of a clan, under the leadership of a chief or clan administrator. The office of the chief should be regulated, complete with allowances for clan representatives and disciplinary measures for breaches of protocol. This will make that office accountable, while the allowances will provide the incentives. In fact, the local level land offices should be the strongest in the land administration chain. They can keep their own land registry to track land transactions in their areas of jurisdiction.

The National Land Commission should be revamped in line with desired reforms, espoused in the policy of 2009. It should be allowed to collect fees and levies for improved administrative purposes. The role of the Commission in land administration and management should be repositioned to give it more authority to represent the larger interests of Kenyans. Indeed, it is questionable, which policy directions have informed some of the recent amendments to the land laws of 2012.

Further, there are emerging frontiers of land use, such as the trading in carbon credits based on land and land resources, and large scale land acquisitions that will require more transformative applications of property law or other laws, in order to secure the land rights of the affected communities.

Recent figures indicate that nearly half of global rural populations do not enjoy security of tenure in land, and that this is a major cause of poverty (United Nations Human Settlements Programme, 2008). The idea that local people do have a right to use, own, and control developments on their land has created the issue that land rights are indeed human rights.

A comprehensive, objective and transparent land tenure regime is critical to the realization of land rights. The current three tier land tenure in Kenya for land administration and management are clearly inadequate as 
they fail to address the bundle of rights pertaining to land and land resources. Other models which accommodate more rights should be explored. The private land tenure model, in its absolute provisions, is discriminatory as it compromises the land rights of the weaker sections of society. It needs to be suitably constrained through various modes of regulations, in order to ensure that it does not become exploitative. Such regulations must also focus on containing the land markets to avoid unrealistic price hikes of land, which limits access.

This may be addressed by improved governance structures and more public participation in decision-making. Even though the Constitution of Kenya 2010, a radical reform in itself, provides for public participation, there are no universally acceptable norms and guidelines on how this ought to be carried out, and what therefore forms the threshold for adequate public participation. This is an imperative if land rights of all Kenyans are to be achieved, especially the land rights of the weaker, vulnerable, and marginalized communities and segments of society.

Regarding the indigenous communities, that seek to inhabit forested areas, the same should also consider the overall functions of forests to humanity in the provision of goods and services, and tailor their land use practices to focus on conservation of these forests. The land rights of such communities must be addressed in policy and legal documents in the respective sectors, and implemented in a participatory manner, in order to take care of their unique interests.

In conclusion, it can be said that the recognition of land rights of the entire community, through comprehensive tenure regimes, will promote sustainable and productive use of land, enhance productivity in the sector, and help achieve some of the goals of sustainable development. Necessary policy, legal and institutional reforms must accompany such initiatives. Equally, proper and simple conflict resolution mechanisms must be provided in the process of land administration.

\section{References}

Community Land Act of Kenya. (2016). Retrieved from http://kenyalaw.org/kl/fileadmin/pdfdownloads/Acts/CommunityLandAct_27of2016.pdf

Constitution of Kenya (COK). (2010). The Constitution of Kenya: Chapter Four on the bill of rights. Retrieved from http://www.klrc.go.ke/index.php/constitution-of-kenya/110-chapter-four-the-bill-of-rights

Ellis, J., \& Galvin, K. A. (1994). Climate patterns and land-use practices in the dry zones of Africa. BioScience, 44(5), $340-349$.

Food and Agricultural Organization of the United Nations (FAO). (2002). FAO land tenure studies, 3. Land tenure and rural development. Rome.

Hussein, H. A., \& Mckay, F. (2003). Access denied: Palestinian land rights in Israel. London; New York: Zed Books.

International Land Coalition (ILC). (2003). Towards a common platform on access to land: The catalyst to reduce rural poverty and the incentive for sustainable natural resource management. Rome.

Johnson, O. E. (1972). An economic analysis, the legal framework and land tenure systems. Journal of Law and Economics, 15(1), 259-276.

Kenya Constitution. (2010). The Constitution of Kenya and the national land policy. Land Governance and Development Institute.

Klepper, G., \& Petersonnja, S. (2005). Trading hot-air. The influence of permit allocation rules, market power and the US withdrawal from the Kyoto protocol. Environmental \& Resource Economics, 32(2), 205-228.

Manne, A., \& Richels, R. (2004). The impact of learning-by-doing on the timing and costs of CO2 abatement. Energy Economics, Elsevier, 26(4), 603-619.

National Land Commission. (2012). A handbook of land laws. Retrieved from http://www.landcommission.go.ke/media/erp/upload/nationallandcommission5of2012.pdf

Ntiati, P. (2002). Group ranches subdivision study in Loitokitok division of Kajiado District, Kenya: Land use change impacts and dynamics (LUCID). Project Working Paper, 19. Nairobi: International Livestock Research Institute. 


\section{LAND RIGHTS AS AN IMPERATIVE FOR SUSTAINABLE LAND AND NATURAL RESOURCES}

Plant, R. (1993). Land rights in human rights and development: Introducing a new ICJ initiative. International Commission of Jurists Revue, Geneva, Switzerland, (51), 10-30.

Sessional Paper No. 3. (2009). The Kenya national land policy. Retrieved from http://extwprlegs1.fao.org/docs/pdf/ken163862.pdf

The Forest Conservation and Management Act. (2016). In Kenya Gazette supplement No. 155 (Act No. 34). Retrieved from http://kenyalaw.org/kl/fileadmin/pdfdownloads/Acts/ForestConservationandManagementActNo34of2016.pdf

United Nations Human Settlements Programme (UN-HABITAT). (2008). Secure land rights for all. Nairobi, Kenya: UN-HABITAT; Global Land Tool Network (GLTN).

Waiganjo, C., \& Ngugi, P. E. (2001). The effects of existing land tenure systems on land use in Kenya today. In Proceedings from International Conference on Spatial Information for Sustainable Development, October, 2-5, Nairobi, Kenya. 